\title{
Assessing Growth Parameters from Culm Cuttings of Bambusa vulgaris at the University of Dschang Botanic Garden, West Region of Cameroon: Implications for the Bamboo Resource Base and Rural Livelihoods
}

\author{
Gilles Ananfack1, Baurel Atchombou1, Herman T. Zanguim¹, Nyong Princely Awazi2* ${ }^{*}$, \\ Steve N. Tassiamba1, Loic T. Tientcheu1, Barnabas Neba Nfornkah', Rene Kaam³, \\ Martin N. Tchamba ${ }^{1}$

\begin{abstract}
${ }^{1}$ Laboratory of Environmental Geomatics, Department of Forestry, Faculty of Agronomy and Agricultural Sciences, The University of Dschang, Dschang, Cameroon

${ }^{2}$ Department of Forestry and Wildlife Technology, College of Technology, The University of Bamenda, Bambili, Cameroon

${ }^{3}$ The International Bamboo and Rattan Organization (INBAR), Yaoundé, Cameroon

Email: *nyongprincely@gmail.com, *awazinyong@uniba.cm
\end{abstract}

How to cite this paper: Ananfack, G., Atchombou, B., Zanguim, H. T., Awazi, N. P., Tassiamba, S. N., Tientcheu, L. T., Nfornkah, B. N., Kaam, R., \& Tchamba, M. N. (2022). Assessing Growth Parameters from Culm Cuttings of Bambusa vulgaris at the University of Dschang Botanic Garden, West Region of Cameroon: Implications for the Bamboo Resource Base and Rural Livelihoods. Open Journal of Forestry, 12, 88-106. https://doi.org/10.4236/ojf.2022.121005

Received: October 12, 2021

Accepted: January 7, 2022

Published: January 10, 2022

Copyright $\odot 2022$ by author(s) and Scientific Research Publishing Inc. This work is licensed under the Creative Commons Attribution International License (CC BY 4.0).

http://creativecommons.org/licenses/by/4.0/

c) (i) Open Access

\begin{abstract}
Dwindling supplies of bamboo resources and the increase in the demand for bamboo have led to the need for better propagation techniques. This is the only way to ensure the sustainability of the bamboo resource base and improve livelihoods. Thus, this study was carried out to examine the different growth parameters of culm cuttings of Bambusa vulgaris in propagation beds with a substrate consisting of dark soil, manure (compost) and sand in a ratio of 1:1:1. Data on different growth parameters was collected on a daily basis over a three week period and analyzed using appropriate descriptive and inferential statistics. It was found that the different growth parameters (diameter, height, leaves and sheaths) of culm cuttings of $B$. vulgaris evolved in like manner in three propagation beds. Descriptive statistics for growth parameters of culm cuttings of $B$. vulgaris showed little or no differences across three shelter/propagation beds (shelter bed 1 , shelter bed 2 and shelter bed 3) with $1.4675 \pm 1.6172 \mathrm{~cm}, 93 \pm 112 \mathrm{~cm}, 22 \pm 30$ leaves, and $4 \pm 6$ sheaths being the mean diameter, height, number of leaves and number of sheaths for all three propagation beds, respectively. ANOVA test showed no statistically significant variation $(p>0.05)$ between growth parameters of culm cuttings of $B$. vulgaris across the three propagation beds, implying that the different growth parameters were relatively similar. Pearson correlation showed the existence
\end{abstract}


of direct and inverse relationships between the different growth parameters of culm cuttings of bamboo. The existence of these direct and inverse relationships could be attributed to the rapid growth rate of bamboo, the substrate used, and the species of bamboo used (B. vulgaris). The study recommends more large-scale propagation projects of this bamboo species in order to ensure the sustainability of the bamboo resource base and improve livelihoods of bamboo dependent rural communities.

\section{Keywords}

Bamboo, Bambusa vulgaris, Growth Parameters, Culm Cuttings, University of Dschang Botanic Garden, Cameroon

\section{Introduction}

The demand for bamboo and its products is growing rapidly while supply remains almost constant due to dependence on natural bamboo resources which are reducing in stock (Liese, 1999; Chung and Yu, 2002; Choudhury et al., 2012; Chaowana, 2013; Kaware et al., 2013; Shukla et al., 2015; Ray and Ali, 2017; Poudel, 2020). To bridge the gap between demand and supply of bamboo, there is an absolute need for large-scale propagation of bamboo through appropriate propagation techniques (Ray and Ali, 2017). Some of these propagation techniques include vegetative and seed-based propagation. Seed-based propagation has been very difficult owing to the relatively long timeframe it takes for bamboo to produce seed and the dormant nature of most bamboo seed (Saad et al., 2016). Vegetative propagation of bamboo through culm cuttings has been observed to be the simplest and most cost-effective method developed over the last few decades (Ruíz-Pérez et al., 2004; Hossain et al., 2006; Bhol and Nayak, 2012; Bhol and Parida, 2015; Ray and Ali, 2017). Better propagation techniques have led to more bamboo agroforestry practices (Nath et al., 2009; Banerjee et al., 2009; Tewari et al., 2015; Kittur et al., 2016; Nirala et al., 2018; Abdullah et al., 2019; Dev et al., 2020; Garima et al., 2021).

Asia remains the most bamboo rich region in the world. It has been estimated that 20 million hectares of bamboo (equivalent to $80 \%$ of total world stock) exist in India, China and Myanmar (Mishra, 2015). Most of Asia's bamboo products are supplied from natural forests, including China, India and Myanmar where 99\% of bamboo products are supplied from natural bamboo forests (Agnihotri and Nandi, 2009; Nongdam and Tikendra, 2014; Yi, 2018). China continues to be the largest bamboo rich nation in the world, having 500 species in 40 genera (Yuming et al., 2004) distributed in 7.6 million hectares of forest land (Ruíz-Pérez et al., 2004).

In sub-Saharan Africa, bamboo is increasingly becoming an important resource owing to its ability to perform different functions (Anglaaere et al., 2020; Akoto et al., 2020; Solomon et al., 2020). Its multifunctional nature has made it a 
friend to both local peasants living in villages across the sub-region as well as urban dwellers who enjoy bamboo finished products like chairs, tables, cupboards, flutes, cups, spoons and many more (Partey et al., 2017; Gebretsion and Abay, 2020). However, there are also some communities especially in the rural areas which see bamboo as an invasive species worth destroying. These communities have destroyed large expanses of bamboo forest through burning or wanton cutting in a bid to do away with what they consider as a worthless and invasive plant species. The International Bamboo and Rattan Organization (INBAR) through its educational and sensitization missions in the sub-region has reduced some of these negative perceptions about bamboo and many of these reticent communities are now increasing preserving bamboo resources in their communities. Bamboo agroforestry systems are growing across the sub-region as peasant farmers integrate bamboo in their farming systems (Partey et al., 2017; Anglaaere et al., 2020; Akoto et al., 2020; Gebretsion and Abay, 2020).

In Cameroon, bamboo is one of the many non-timber forest products (NTFPs) which had been neglected in the past (Ingram et al., 2010; Ingram and Tieguhong, 2012; Fozao et al., 2015; Nfornkah et al., 2018; Nfornkah et al., 2020c; Nfornkah et al., 2021a, 2021b, 2021c; Chimi et al., 2021). With increasing awareness raised especially by INBAR and owing to dwindling forest resources, bamboo has become an important alternative (Mankou, 2018). Bamboo supplies a plethora of ecosystem services (food, medicine, fibre, soil fertility enhancement, climate change mitigation, landscape restoration and many others) (Nfornkah et al., 2020a, 2020b) as well as semi-finished and finished products like chairs, tables, flutes, cupboards, beds, cups, and many other ornamental products (Ingram et al., 2010; Fokwa et al., 2012; Ingram and Tieguhong, 2012; Chimi et al., 2021; Sikame-Tagne et al., 2021). The bamboo sub-sector in Cameroon has gained a lot of momentum especially with the spread of INBAR's activities across the country through partnerships with universities like the University of Dschang, as well as ministries like the ministry of forestry. The creation of a bamboo factory in Yaoundé is equally a step in the right direction. With bamboo having huge potential to drive the economy of Cameroon, the question flying in the air is: where will the bamboo resources come from? Bamboo in Cameroon is mainly found in nature, which means supply will dwindle in the future if measures are not taken to increase the existing bamboo stock. To ensure a sustainable supply of bamboo, there is an absolute need to domesticate bamboo which can be done through the adoption of proper propagation techniques. It is within this framework that this study comes in. The study was carried out to understand how a substrate consisting of dark soil, manure (compost) and sand in a ratio of 1:1:1 in three propagation beds could affect different growth parameters of culm cuttings of $B$. vulgaris. The objective was to foster the propagation of $B$. vulgaris in order to ensure the sustainability of the bamboo resource base and contribute towards improving the livelihoods of rural bamboo-dependent communities. 


\section{Materials and Methods}

\subsection{Description of the Study Area}

The study was carried out from the 1 st to the $21^{\text {st }}$ of May, 2021 at the nursery of the University of Dschang Botanic Garden (Figure 1). The objective was to study the growth parameters of culm cuttings of Bambusa vulgaris obtained from the nursery of the University of Dschang Botanic Garden, west region of Cameroon.

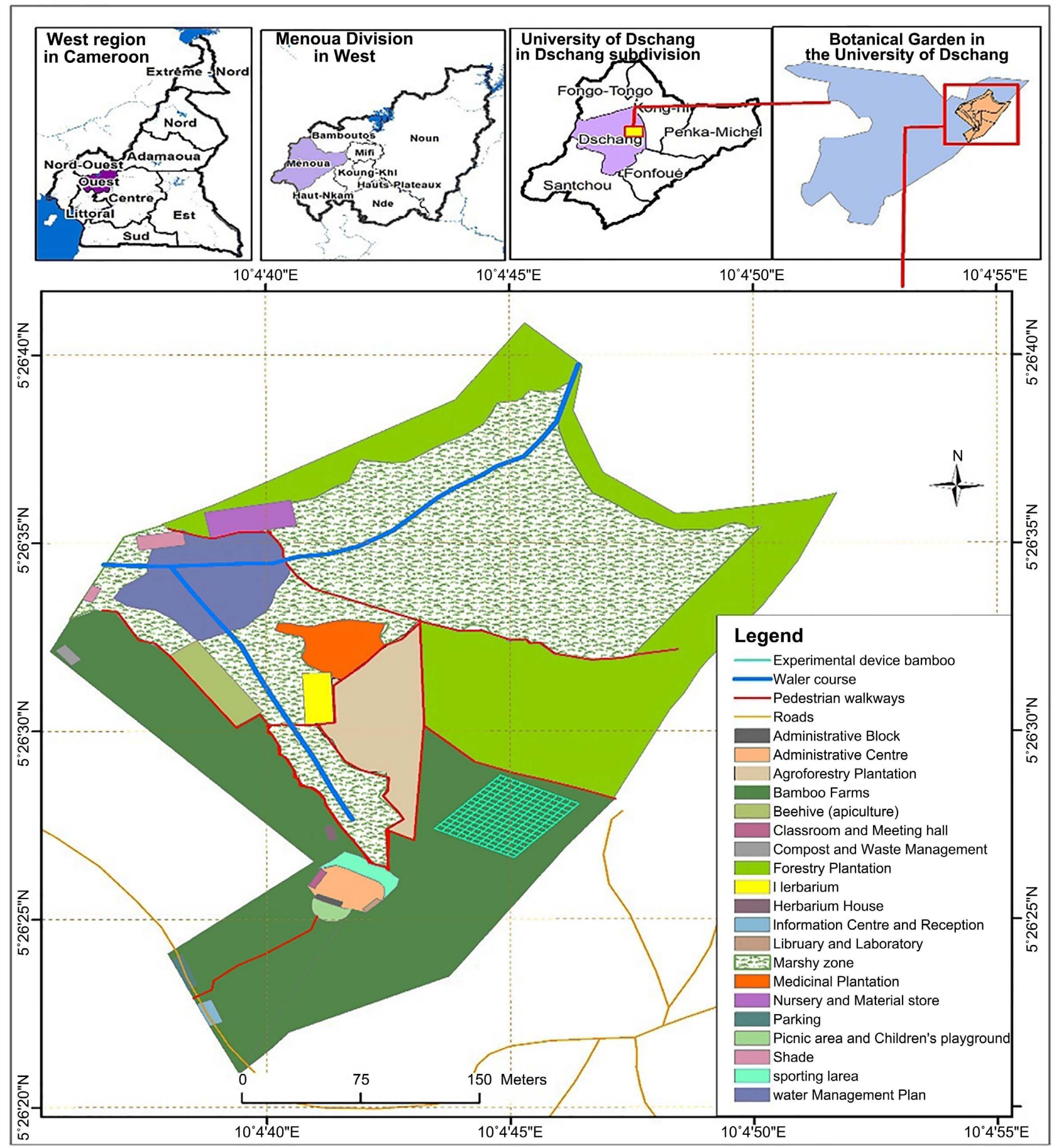

Figure 1. Map of the study area. 
Dschang has a tropical highland climate characterized by two seasons i.e. short dry season (5 months-October to March) and long rainy season (7 monthsMarch to October). The average annual temperature in Dschang is $19.7^{\circ} \mathrm{C}$. The average annual rainfall is $4473 \mathrm{~mm}$. The hottest month of the year is February with an average temperature of $21.5^{\circ} \mathrm{C}$. In August, the average temperature is $18.1^{\circ} \mathrm{C}$. August is therefore the coldest month of the year with the highest relative humidity (91.73\%).

\subsection{Data Collection}

Three propagation/shelter beds with an area of $1.20 \mathrm{~m}$ wide $\times 5 \mathrm{~m}$ long were used for this experiment. The propagation substrate consisted of dark soil, manure (compost) and sand in a ratio of 1:1:1. The use of a similar substrate across the three propagation beds was done purposely in order to determine how good it was for the propagation of culm cuttings of $B$. vulgaris considering that the substrate is easily accessible and cheap, and could be used easily by peasants in rural communities to propagate $B$. vulgaris. However, more work is being done presently to test different substrates in order to see the most appropriate for the propagation of culm cuttings of $B$. vulgaris.

Culm cuttings of bamboo with lengths of $1 \mathrm{~m}$ were collected from the bamboo forest of the Foréké-Dschang escarpment located some $9 \mathrm{~km}$ from Dschang urban centre. Once the culm cuttings were brought to the nursery of the University of Dschang Botanic Garden, both ends of each of the culm cuttings were filled with mud made up of a mixture of moist soil and cow dung in order to limit evapotranspiration and prevent water from seeping into the cuttings. The cuttings were then placed in staggered rows in the propagation beds, reversing the orientation of the buds each time, with a distance of $10 \mathrm{~cm}$ between the cuttings. Each bed contained 50 culm cuttings. Each culm cutting had 2 to 3 nodes-the growth points for the new plants. Two weeks after the culm cuttings were placed in the propagation beds and after the growth parameters started showing signs in the propagation beds, a mechanism to collect data for the different growth parameters was set up. This system was based on simple random sampling. In each of the monitored beds, at least $30 \%$ of the cuttings, i.e. 20 of the 50 , were selected randomly. Each culm cutting was labelled (with numbers). Thus, 60 culm cuttings were monitored during this study for 21 days after the start of their growth. Each labelled plant (20 plants/propagation bed) had its growth parameters collected daily from 7:00 am to 9:00 am. These parameters were diameter, height, number of leaves, and the number of mature sheaths on the shoots emerging from the culm cuttings. The materials used included: a folding saw for collecting cuttings, calipers for diameter measurement and double decameter for height measurement. Data was collected using a data collection sheet and imputed into an Excel spreadsheet for analysis.

\subsection{Data Analysis}

Data analysis was done on Excel version 13 and SPSS version 17. Descriptive and 
inferential statistics were computed. Descriptive statistics were graphs, dispersion parameters and percentage indices. Inferential statistics included ANOVA and Pearson correlation. ANOVA was used to assess the degree of variation between growth parameters across three propagation beds. Correlation was used to assess the relationship between different growth parameters of culm cuttings of B. vulgaris in three propagation beds.

\section{Results and Discussion}

\subsection{Evolution in Growth Parameters of Bamboo Cuttings of B. vulgaris on Different Propagation/Shelter Beds}

The different growth parameters (diameter, height, leaves and sheaths) of cuttings of Bambusa vulgaris evolved in like manner in three propagation beds containing similar substrates of dark soil, manure (compost) and sand in the ration 1:1:1 (Figures 2-4). Within the 21 days (three weeks) under consideration, height and number of leaves showed an increasing trend for the three propagation beds. Number of sheaths on its part increased for the first 12 days and decreased from the $13^{\text {th }}$ to the $21^{\text {st }}$ day for the three propagation beds.

Diameter was more or less stagnant across the 21 days for the three propagation beds. The increasing trend observed in height and leaves could be attributed to the rapid growth rate of bamboo. The decreasing trend observed in number of sheaths from the $13^{\text {th }}$ day to the $21^{\text {st }}$ day could be attributed to the fact that younger bamboo generally tends to have more sheaths than their more mature counterparts. The more or less stagnant diameter across the entire 21 days could be attributed to the relatively short duration of the study ( 3 weeks) which was not sufficient enough for the bamboo cuttings to develop a relatively larger diameter.

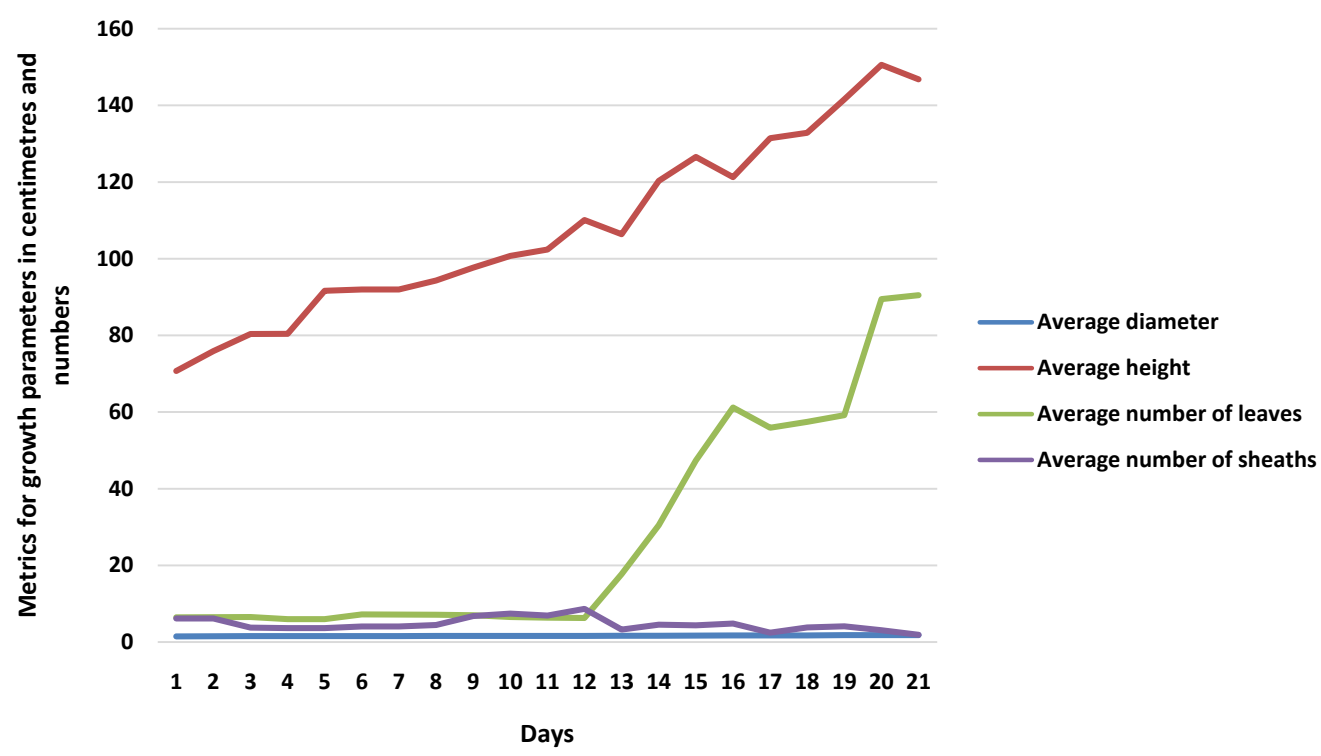

Figure 2. Graph showing changes in growth parameters of culm cuttings of B. vulgaris within 21 days for shelter/propagation bed 1 . 


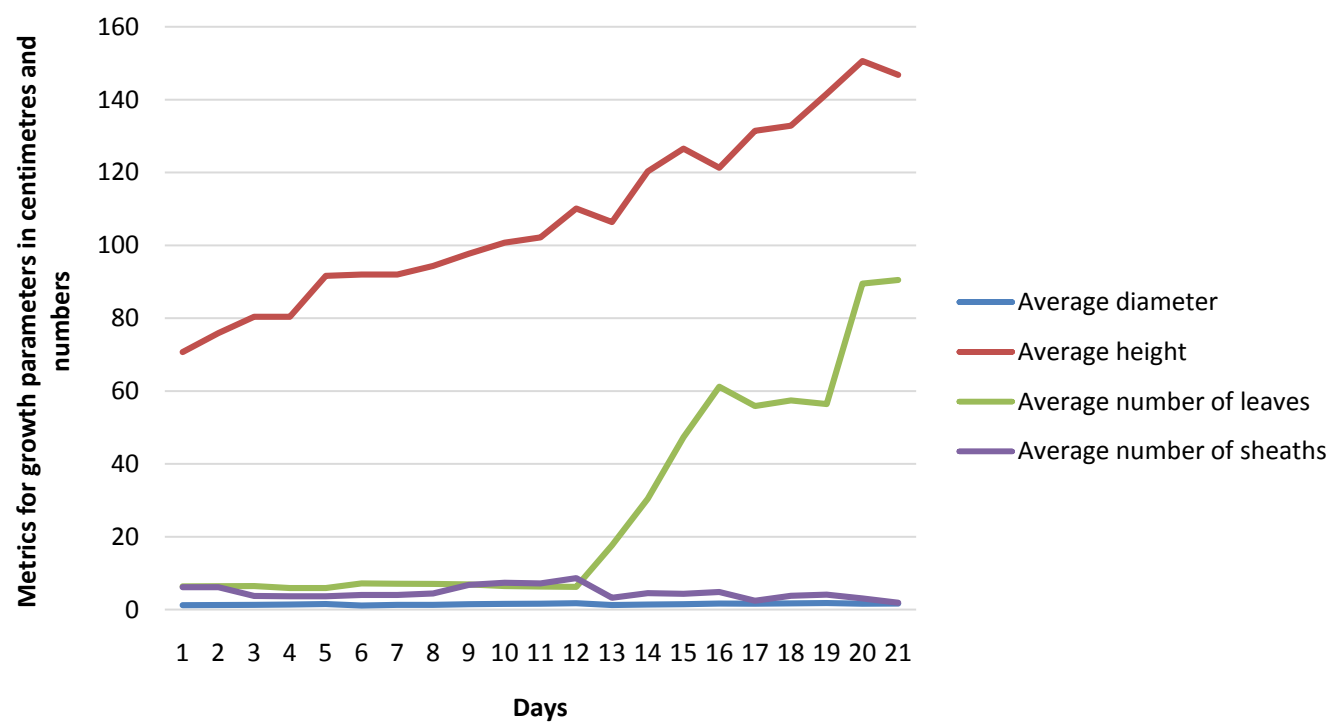

Figure 3. Graphs showing changes in growth parameters of bamboo cuttings within 21 days for propagation/shelter bed 2 .

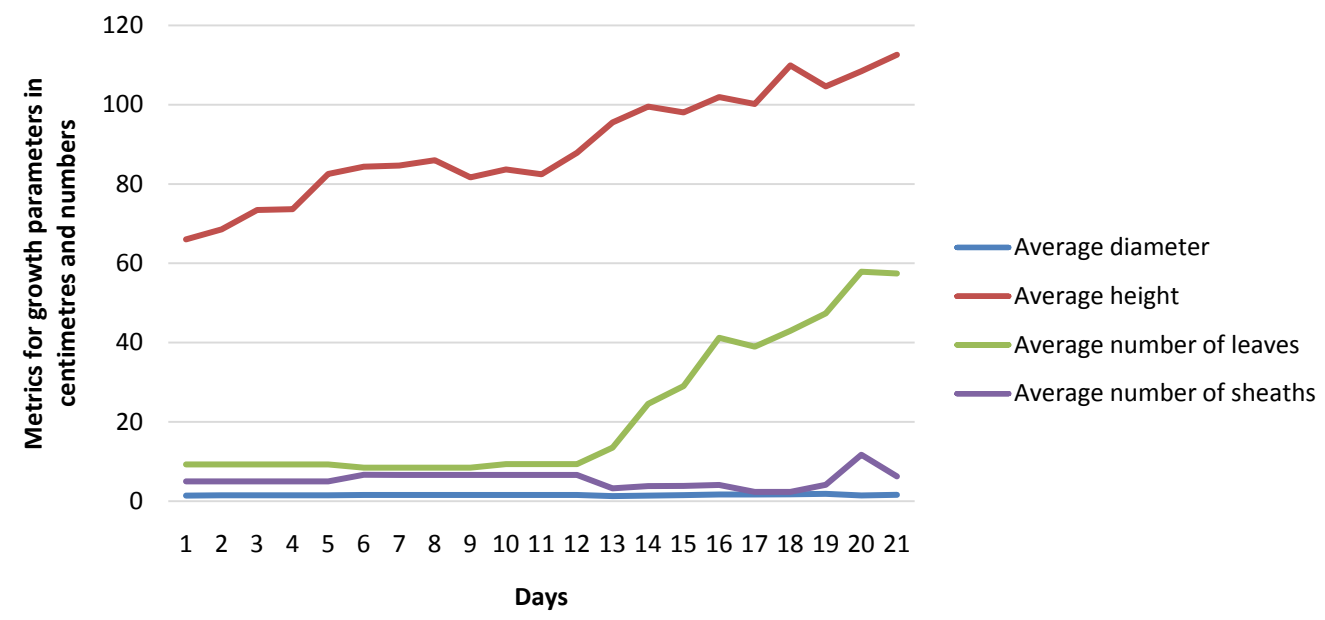

Figure 4. Graphs showing changes in growth parameters of bamboo cuttings within 21 days for propagation/shelter bed 3.

Studies assessing the evolution in growth parameters of bamboo in general and $B$. vulgaris in particular within the framework of propagation of culm cuttings of bamboo are limited. In Cameroon, the only studies found were those of Nfornkah et al., 2020a, 2020b; and Nfornkah et al., 2021a, 2021b, 2021c which mainly focused on carbon stock measurement within natural bamboo forests. However around other parts of the world especially in Asia some studies have been conducted measuring growth parameters of culm cuttings of some Bambusa species (Pattanaik et al., 2004; Hossain et al., 2006; Islam et al., 2011; Joshi et al., 2012; Bhol and Nayak, 2012; Senyanzobe et al., 2013; Bhol and Parida, 2015; Gaintait et al., 2016; Ray and Ali, 2016). Our study however focused on $B$. vulgaris and did a more exhaustive study of different growth parameters (diameter, height, number of leaves and number of sheaths). 


\subsection{Descriptive Statistics for Growth Parameters of Culm Cuttings of $B$. vulgaris in Three Propagation Beds}

Descriptive statistics for growth parameters (diameter, height, number of leaves, and number of sheaths) of bamboo cuttings of Bambusa vulgaris showed little or no differences across the three shelter/propagation beds (shelter bed 1, shelter bed 2 and shelter bed 3) (Table 1). For diameter, the means for shelter beds 1, 2 and 3 were $1.4240 \pm 1.7660 \mathrm{~cm}, 1.3945 \pm 1.5905 \mathrm{~cm}$ and $1.4090 \pm 1.6700 \mathrm{~cm}$, respectively, with $1.4675 \pm 1.6172 \mathrm{~cm}$ being the mean diameter for all three shelter beds. For plant height, the mean for shelter beds 1, 2 and 3 were $95 \pm 126 \mathrm{~cm}, 92$ $\pm 124 \mathrm{~cm}$ and $72 \pm 108 \mathrm{~cm}$, respectively, with $93 \pm 112 \mathrm{~cm}$ being the mean height for all three shelter beds. For number of leaves, it was found that the mean number of leaves for shelter beds/propagation beds 1, 2 and 3 were $20 \pm 36$ leaves, $20 \pm$ 36 leaves and $14 \pm 30$ leaves, respectively, with the overall mean for the three shelter beds being $22 \pm 30$ leaves. Regarding number of sheaths, it was found that the mean number of sheaths for shelter beds 1,2 and 3 were $3 \pm 8$ sheaths, 4 \pm 5 sheaths and $4 \pm 6$ sheaths, respectively, with the overall mean for the three shelter beds being $4 \pm 6$ sheaths. From these statistics, no significant difference existed between diameter, height, number of leaves and number of sheaths across the three propagation/shelter beds. This could be attributed to the fact that a

Table 1. Descriptive statistics for different growth parameters of culm cuttings of $B$. vulgaris.

\begin{tabular}{|c|c|c|c|c|c|c|c|c|c|}
\hline & & \multirow{2}{*}{$\mathbf{N}$} & \multirow{2}{*}{ Mean } & \multirow{2}{*}{$\begin{array}{c}\text { Std. } \\
\text { Deviation }\end{array}$} & \multirow{2}{*}{ Std. Error } & \multicolumn{2}{|c|}{$\begin{array}{l}95 \% \text { Confidence } \\
\text { Interval for Mean }\end{array}$} & \multirow{2}{*}{ Minimum } & \multirow{2}{*}{ Maximum } \\
\hline & & & & & & $\begin{array}{l}\text { Lower } \\
\text { Bound }\end{array}$ & $\begin{array}{l}\text { Upper } \\
\text { Bound }\end{array}$ & & \\
\hline \multirow{4}{*}{$\begin{array}{c}\text { Average Plant } \\
\text { diameter for } 21 \\
\text { days }\end{array}$} & Shelter bed 1 & 20 & 1.5950 & 0.36542 & 0.08171 & 1.4240 & 1.7660 & 1.07 & 2.26 \\
\hline & Shelter bed 2 & 20 & 1.4925 & 0.20941 & 0.04682 & 1.3945 & 1.5905 & 1.18 & 2.11 \\
\hline & Shelter bed 3 & 20 & 1.5395 & 0.27882 & 0.06235 & 1.4090 & 1.6700 & 1.02 & 1.92 \\
\hline & Total & 60 & 1.5423 & 0.28973 & 0.03740 & 1.4675 & 1.6172 & 1.02 & 2.26 \\
\hline \multirow{4}{*}{$\begin{array}{l}\text { Average plant } \\
\text { height for } 21 \text { days }\end{array}$} & Shelter bed 1 & 20 & 110.4015 & 33.61479 & 7.51650 & 94.6693 & 126.1337 & 62.74 & 176.55 \\
\hline & Shelter bed 2 & 20 & 107.8940 & 34.55407 & 7.72652 & 91.7222 & 124.0658 & 62.74 & 176.55 \\
\hline & Shelter bed 3 & 20 & 89.7745 & 38.85734 & 8.68877 & 71.5887 & 107.9603 & 25.31 & 142.67 \\
\hline & Total & 60 & 102.6900 & 36.33879 & 4.69132 & 93.3027 & 112.0773 & 25.31 & 176.55 \\
\hline \multirow{4}{*}{$\begin{array}{l}\text { Average plant } \\
\text { number of leaves } \\
\text { for } 21 \text { days }\end{array}$} & Shelter bed 1 & 20 & 28.0005 & 16.75689 & 3.74696 & 20.1580 & 35.8430 & 6.38 & 64.29 \\
\hline & Shelter bed 2 & 20 & 27.8685 & 16.83474 & 3.76436 & 19.9896 & 35.7474 & 6.38 & 64.29 \\
\hline & Shelter bed 3 & 20 & 21.9910 & 17.66409 & 3.94981 & 13.7240 & 30.2580 & 1.43 & 71.57 \\
\hline & Total & 60 & 25.9533 & 17.03406 & 2.19909 & 21.5530 & 30.3537 & 1.43 & 71.57 \\
\hline \multirow{4}{*}{$\begin{array}{l}\text { Average plant } \\
\text { number of sheath } \\
\text { for } 21 \text { days }\end{array}$} & Shelter bed 1 & 20 & 5.7695 & 5.19168 & 1.16090 & 3.3397 & 8.1993 & 2.24 & 27.24 \\
\hline & Shelter bed 2 & 20 & 4.6800 & 1.20694 & 0.26988 & 4.1151 & 5.2449 & 2.24 & 7.14 \\
\hline & Shelter bed 3 & 20 & 5.2835 & 1.88188 & 0.42080 & 4.4028 & 6.1642 & 1.67 & 10.24 \\
\hline & Total & 60 & 5.2443 & 3.23906 & 0.41816 & 4.4076 & 6.0811 & 1.67 & 27.24 \\
\hline
\end{tabular}


similar substrate was used in all three shelter beds, as well as the relatively short duration of the data collection process (3 weeks). It could equally be attributed to the fact that a similar bamboo species (Bambusa vulgaris) was used in all three shelter/propagation beds.

In Cameroon, the only studies carried out on the growth parameters of bamboo were done in the natural bamboo forest within the framework of carbon stock measurement (Nfornkah et al., 2020a, 2020b; Nfornkah et al., 2021a, 2021b, 2021c). This study however focused on growth parameters from culm cuttings of $B$. vulgaris within the framework of assessing how B. vulgaris can be propagated using different propagation beds. Most of the studies that have examined different propagation techniques of bamboo are found in Asia especially in Asia and India (Banik, 1995; Singh et al., 2006; Singh et al., 2013; Tripathi, 2009; Razvi et al., 2011; Lin et al., 2012; Chhetri and Kumar, 2015; Saad et al., 2016). This study is however among the few studies to have examined in close detail the different growth parameters of culm cuttings of $B$. vulgaris.

\subsection{Variations in Growth Parameters of Culm Cuttings of Bambusa vulgaris in Three Propagation Beds}

Inferential statistics from ANOVA test showed no statistically significant variation between growth parameters (diameter, height, number of leaves and number of sheaths) between growth parameters of culm cuttings of B. vulgaris and three propagation/shelter beds (Table 2).

Diameter $(\mathrm{F}=0.619, p=0.542)$, height $(\mathrm{F}=1.983, p=0.147)$, number of leaves $(\mathrm{F}=0.807, p=0.451)$ and number of sheaths $(\mathrm{F}=0.559, p=0.575)$ did not vary significantly with propagation/shelter beds. This implies that at $5 \%$

Table 2. ANOVA statistics showing degree of variation in growth parameters of culm cuttings of $B$. vulgaris between shelter/propagation beds.

\begin{tabular}{|c|c|c|c|c|c|c|}
\hline & & $\begin{array}{l}\text { Sum of } \\
\text { Squares }\end{array}$ & df & $\begin{array}{l}\text { Mean } \\
\text { Square }\end{array}$ & $\mathbf{F}$ & Sig. \\
\hline \multirow{3}{*}{$\begin{array}{c}\text { Average Plant } \\
\text { diameter for } 21 \\
\text { days }\end{array}$} & Between Groups & 0.105 & 2 & 0.053 & 0.619 & 0.542 \\
\hline & Within Groups & 4.847 & 57 & 0.085 & & \\
\hline & Total & 4.953 & 59 & & & \\
\hline \multirow{3}{*}{$\begin{array}{l}\text { Average plant } \\
\text { height for } 21 \text { days }\end{array}$} & Between Groups & 5067.180 & 2 & 2533.590 & 1.983 & 0.147 \\
\hline & Within Groups & $72,842.778$ & 57 & 1277.943 & & \\
\hline & Total & $77,909.958$ & 59 & & & \\
\hline \multirow{3}{*}{$\begin{array}{c}\text { Average plant } \\
\text { number of leaves } \\
\text { for } 21 \text { days }\end{array}$} & Between Groups & 471.177 & 2 & 235.588 & 0.807 & 0.451 \\
\hline & Within Groups & $16,648.215$ & 57 & 292.074 & & \\
\hline & Total & $17,119.392$ & 59 & & & \\
\hline \multirow{3}{*}{$\begin{array}{l}\text { Average plant } \\
\text { number of sheath } \\
\text { for } 21 \text { days }\end{array}$} & Between Groups & 11.916 & 2 & 5.958 & 0.559 & 0.575 \\
\hline & Within Groups & 607.083 & 57 & 10.651 & & \\
\hline & Total & 618.999 & 59 & & & \\
\hline
\end{tabular}


probability level, the different growth parameters (diameter, height, number of leaves, and number of sheaths) were relatively similar across the three propagation beds. Although mean plots (Figures 5-8) showed some slight differences in growth parameters of bamboo cuttings across the three propagation beds, ANOVA statistics override these slight differences, indicating that no variation exists in growth parameters of bamboo across the three propagation beds. The absence of variations in growth parameters across the three shelter/propagation beds could be attributed to the use of the same substrate across the three shelter beds, the use of the same bamboo species (Bambusa vulgaris) and the relatively short duration of the data collection period (21 days).

Studies carried out across different parts of the world have shown different degrees of variation in growth parameters of bamboo cuttings (Mehra and Mehra, 2007; Bareja, 2010; Kaushal et al., 2011; Ntirugulirwa et al., 2012; Gulabrao et al., 2012; Mudoi et al., 2013; Elbasheer and Raddad, 2013; Mulatu and Fetene, 2014; Gebrehiwot et al., 2016). However, few of these studies have been carried

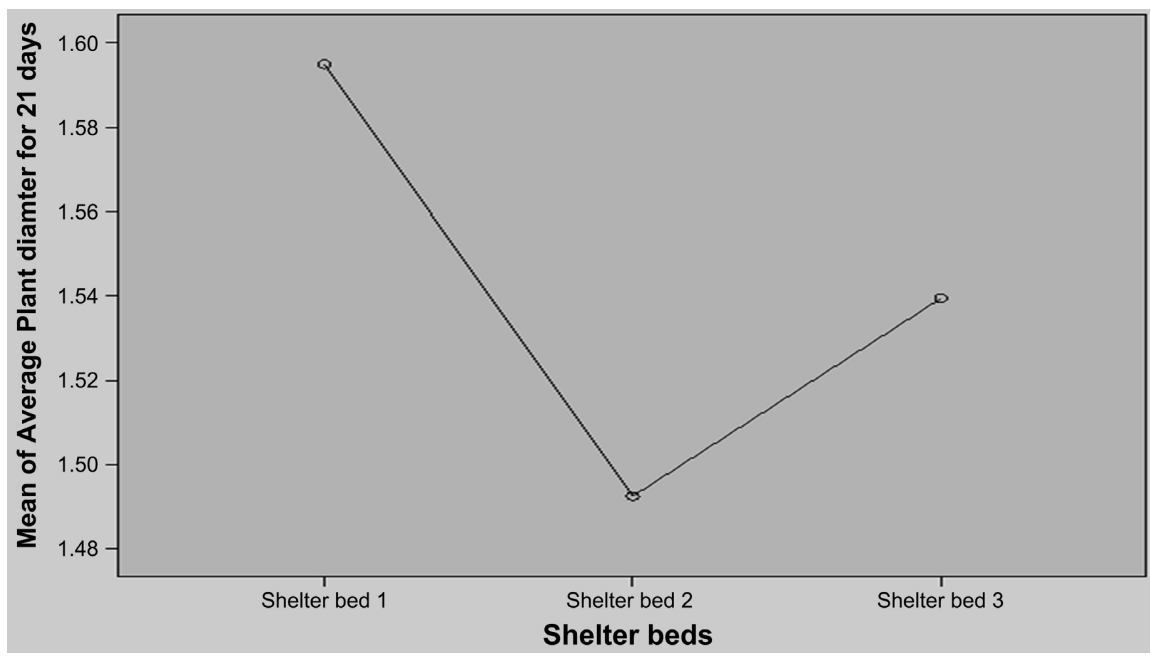

Figure 5. Mean plot for diameter in three propagation/shelter beds.

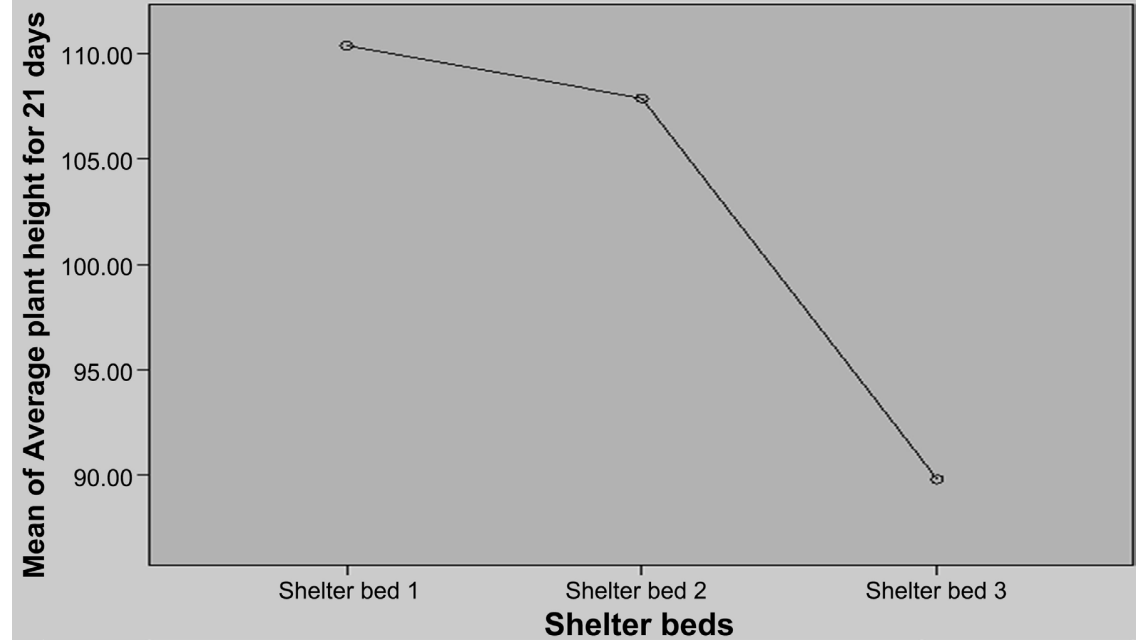

Figure 6. Mean plot for height in three propagation/shelter beds. 


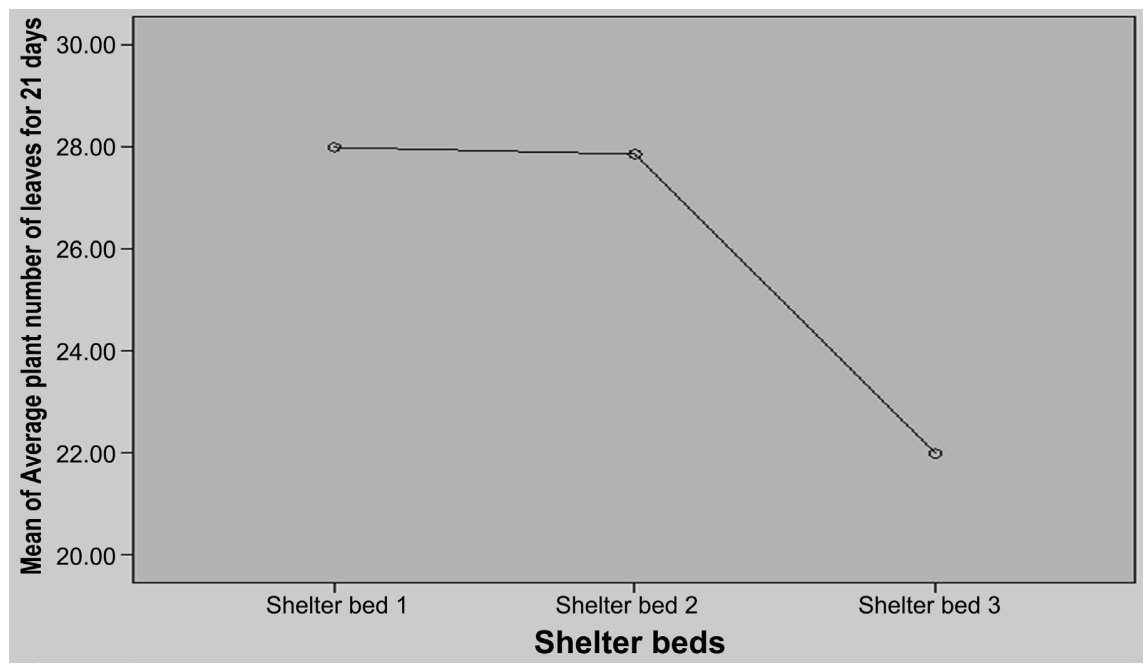

Figure 7. Mean plot for number of leaves in three propagation/shelter beds.

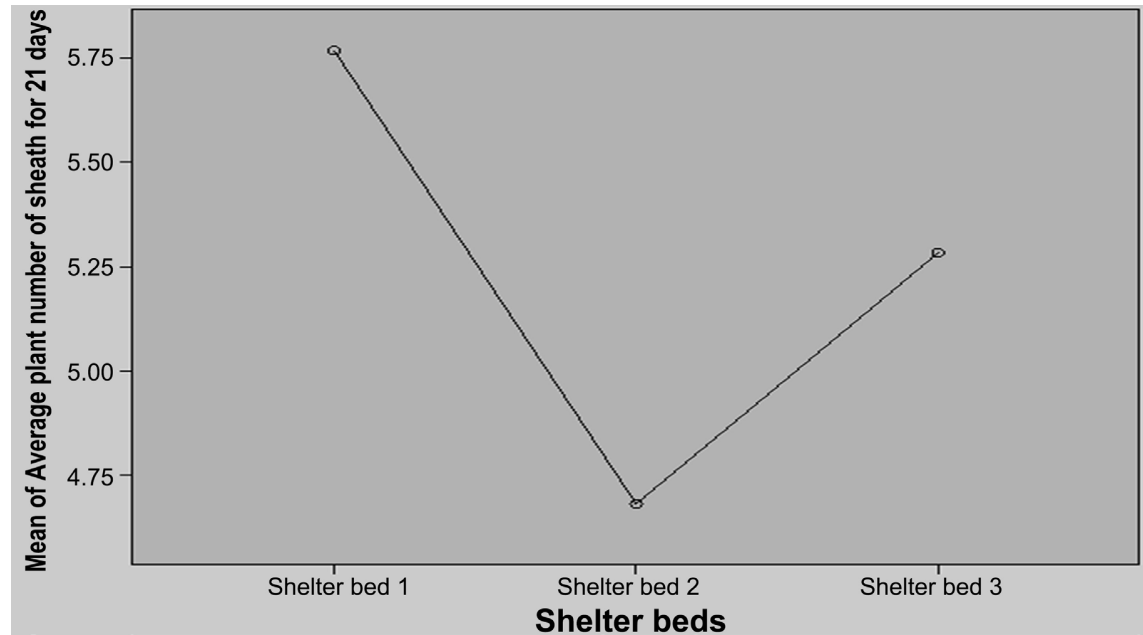

Figure 8. Mean plot for number of sheaths in three propagation/shelter beds.

out on culm cuttings of $B$. vulgaris which was the main objective of this study. In Cameroon, little has been done to assess growth parameters of culm cuttings of bamboo in general and B. vulgaris in particular. This research gap has been filled by this study.

\subsection{Relationship between Growth Parameters of Cuttings of B. vulgaris in Three Propagation Beds}

Pearson correlation coefficients revealed that an inverse relationship exist between diameter and height $(\mathrm{r}=-0.168, p=0.200)$, diameter and number of leaves $(\mathrm{r}=-0.223, p=0.087)$, diameter and number of sheaths $(\mathrm{r}=-0.263, p=$ 0.042) (Table 3). This implies that as diameter increases, there is a plausibility of height, number of leaves and number of sheaths decreasing and vice versa.

A positive or direct relationship existed between height and number of leaves $(\mathrm{r}=0.708, p=0.000)$ as well as height and number of sheaths $(\mathrm{r}=0.223, p=$ 0.088 ), implying that as height increases, there is a plausibility of number of 
Table 3. Correlations between growth parameters of culm cuttings of B. vulgaris and shelter/propagation beds.

\begin{tabular}{|c|c|c|c|c|c|}
\hline & & $\begin{array}{l}\text { Average Plant } \\
\text { diameter for } 21 \\
\text { days }\end{array}$ & $\begin{array}{l}\text { Average plant } \\
\text { height for } 21 \\
\text { days }\end{array}$ & $\begin{array}{c}\text { Average plant } \\
\text { number of leaves } \\
\text { for } 21 \text { days }\end{array}$ & $\begin{array}{l}\text { Average plant } \\
\text { number of sheath } \\
\text { for } 21 \text { days }\end{array}$ \\
\hline \multirow{3}{*}{$\begin{array}{l}\text { Average Plant diameter } \\
\text { for } 21 \text { days }\end{array}$} & Pearson Correlation & 1 & -0.168 & -0.223 & $-0.263\left(^{*}\right)$ \\
\hline & Sig. (2-tailed) & & 0.200 & 0.087 & 0.042 \\
\hline & $\mathrm{N}$ & 60 & 60 & 60 & 60 \\
\hline \multirow{3}{*}{$\begin{array}{l}\text { Average plant height for } \\
21 \text { days }\end{array}$} & Pearson Correlation & -0.168 & 1 & $0.708\left(^{* *}\right)$ & 0.223 \\
\hline & Sig. (2-tailed) & 0.200 & & 0.000 & 0.088 \\
\hline & $\mathrm{N}$ & 60 & 60 & 60 & 60 \\
\hline \multirow{3}{*}{$\begin{array}{l}\text { Average plant number of } \\
\text { leaves for } 21 \text { days }\end{array}$} & Pearson Correlation & -0.223 & $0.708(* *)$ & 1 & $0.299\left(^{*}\right)$ \\
\hline & Sig. (2-tailed) & 0.087 & 0.000 & & 0.020 \\
\hline & $\mathrm{N}$ & 60 & 60 & 60 & 60 \\
\hline \multirow{3}{*}{$\begin{array}{l}\text { Average plant number of } \\
\text { sheath for } 21 \text { days }\end{array}$} & Pearson Correlation & $-0.263\left(^{\star}\right)$ & 0.223 & $0.299\left(^{\star}\right)$ & 1 \\
\hline & Sig. (2-tailed) & 0.042 & 0.088 & 0.020 & \\
\hline & $\mathrm{N}$ & 60 & 60 & 60 & 60 \\
\hline
\end{tabular}

${ }^{\star}$ Correlation is significant at the 0.05 level (2-tailed). ${ }^{\star \star}$ Correlation is significant at the 0.01 level (2-tailed).

leaves and number of sheaths increasing and vice versa. There was also a positive or direct relationship between number of sheaths and height $(\mathrm{r}=0.223, p=$ $0.088)$ as well as number of sheaths and number of leaves $(\mathrm{r}=0.299, p=0.020)$, implying that there is a plausibility of increasing number of sheaths resulting in increasing height and number of leaves and vice versa. The existence of these direct and inverse relationships could be attributed to the rapid growth rate of bamboo, the substrate used, the species of bamboo (Bambusa vulgaris) and the duration of the data collection period (21 days or three weeks). A follow up project is on the way to determine these same growth parameters using different substrates across different propagation beds rather than just a single substrate. This will enable us to see how different substrates influence growth parameters of culm cuttings of $B$. vulgaris in order to propose the most appropriate substrate for the propagation of culm cuttings of $B$. vulgaris.

Although some studies have examined growth parameters of culm cuttings of some Bambusa species including B. vulgaris (Bhol and Nayak, 2012; Bhol and Parida, 2015; Gaintait et al., 2016; Ray and Ali, 2016), few have assessed the relationship between growth parameters of bamboo and the substrate in different propagation beds. This study by doing this has therefore filled a major research gap.

\section{Implications of Bamboo Propagation on the Bamboo Resource Base and Rural Livelihoods}

In Cameroon, little or nothing has been done to understand the different prop- 
agation techniques of bamboo. Considering that almost all the bamboo resources from Cameroon are collected from the wild, bamboo propagation will have major implications on the resource base and rural livelihoods. First the propagation of bamboo will help to increase the existing stock of bamboo thereby reducing pressure on the natural stock of bamboo. This will go a long way to ensure the sustainability of naturally growing bamboo stock as wanton cutting of wild bamboo forest has resulted in dwindling supplies. Secondly, bamboo propagation will encourage the adoption of bamboo agroforestry systems as farmers will be given propagated bamboo plants to plant on their farms. One of the main hindrances to the adoption of bamboo agroforestry systems is the unavailability of good bamboo seedlings. Bamboo agroforestry is a best practice that can help enormously in the fight against climate change, contribute to land restoration and improve livelihoods through the provision of different ecosystem services like carbon sequestration, soil fertility improvement and provisioning services like food, fodder, fuelwood, fibre and income. Thus, the adoption of bamboo agroforestry systems will improve environmental sustainability while enhancing rural livelihoods. Last but not the least, bamboo propagation will allow local communities to understand that bamboo is a viable resource worth valorizing. In the past, mainly tree species especially fruit trees especially fruit trees have been propagated. The propagation of bamboo will show peasant communities that bamboo too is as valuable as tree species. Studies conducted in Cameroon by Degrande et al. (2013), Takoutsing et al. (2013), Takoutsing et al. (2014) and in Nepal by Yadav et al. (2020) have shown that the development of nurseries for the propagation of different species geared towards distribution to peasant communities is the surest way to ensure adoption and improve rural livelihoods. These studies were however carried out mainly on tree species with no consideration of bamboo species. Our study therefore comes in to fill this research gap.

\section{Conclusion and Policy Implications}

The demand for bamboo and its products is growing rapidly while supply has been dwindling due to dependence on natural bamboo resources which are reducing in stock. To bridge the gap between demand and supply of bamboo, there is an absolute need for large-scale propagation of bamboo through appropriate propagation techniques. This study was carried out to fill this research gap and ensure the sustainability of the bamboo resource base especially the resource base of $B$. vulgaris. Findings showed that different growth parameters of culm cuttings of $B$. vulgaris evolved almost in like manner in three propagation beds containing a similar substrate of dark soil, manure (compost) and sand in the ration 1:1:1. A follow up project will use different substrates in the three propagation beds to see the degree of variations in the growth parameters in order to propose the most appropriate propagation substrate for culm cuttings of $B$. vulgaris. Descriptive statistics for growth parameters of culm cuttings of $B$. vulgaris showed little or no differences across the three shelter/propagation beds. ANOVA 
test statistics showed no statistically significant variation between growth parameters of culm cuttings of B. vulgaris and three propagation/shelter beds, implying that the different growth parameters were relatively similar across the three propagation beds which could be attributed to the use of a similar substrate in the three propagation beds. Pearson correlation coefficients revealed that an inverse relationship exists between diameter and height, diameter and number of leaves, diameter and number of sheaths implying that as diameter increases, there is a plausibility of height, number of leaves and number of sheaths decreasing and vice versa. A positive or direct relationship existed between height and number of leaves as well as height and number of sheaths, implying that as height increases, there is a plausibility of number of leaves and number of sheaths increasing and vice versa. There was also a positive or direct relationship between number of sheaths and height as well as number of sheaths and number of leaves, implying that there is a plausibility of increasing number of sheaths resulting in increasing height and number of leaves and vice versa. The existence of these direct and inverse relationships could be attributed to the rapid growth rate of bamboo, the substrate used, the species of bamboo ( $B$. vulgaris) and the duration of the data collection period.

The study recommends more large-scale propagation projects of $B$. vulgaris in particular and other bamboo species in general in order to ensure the sustainability of the bamboo resource base. We are currently undertaking a follow up project where we are using different substrates in different propagation beds in order to propose the most suitable method for propagation of B. vulgaris and other bamboo species. We equally intend to do a more long term study of the growth parameters of culm cuttings of $B$. vulgaris in order to have more concrete findings. Policy makers could take a look at the present findings when formulating policies geared towards ensuring the sustainability of the bamboo resource through propagation of culm cuttings of $B$. vulgaris in particular. This will go a long way to improve the livelihoods of bamboo dependent rural communities who are facing problems of dwindling bamboo supplies in the wild.

\section{Acknowledgements}

We are immensely grateful to the International Bamboo and Rattan Organization (INBAR) for funding this project as well as the University of Dschang for accommodating the project. Special thanks equally go to the Department of Forestry for providing logistics and morale support during the entire duration of the project.

\section{Conflicts of Interest}

Authors declare that there are no competing interests.

\section{References}

Abdullah, W. G., Rianse, U., Zulfikar Ma'ruf, A., Rianse, I. S., Widayati, W., Baka, W. K., 
\& Romantiaulia, W. I. (2019). Potential Use of Bamboo to Support Village Independence. International Journal of Scientific \& Technology Research, 8, 99-105.

Agnihotri, K. A., \& Nandi, K. S. (2009). In Vitro Shoot Cut: A High Frequency Multiplication and Rooting Method in the Bamboo Dendrocalamus hamiltonii. Biotechnology, 8, 259-263.

Akoto, D. S., Partey, S. T., Denich, M., Kwaku, M., Borgemeister, C., \& Schmitt, C. B. (2020). Towards Bamboo Agroforestry Development in Ghana: Evaluation of Crop Performance, Soil Properties and Economic Benefit. Agroforestry Systems, 94, 175-180. https://doi.org/10.1007/s10457-020-00493-7

Anglaaere, L., Djagbletey, G. D., Ofori, D. A., Govina, J. K., Okyere-Agyapong, E., Kwaku, M., \& Acheampong, E. N. (2020). Manual for Bamboo Agroforestry Systems in Ghana (37 p). INBAR (International Network for Bamboo and Rattan).

https://www.inbar.int/wp-content/uploads/2020/11/Nov-2020_WARO_Manual-for-Ba mboo-Agroforestry-Systems-in-Ghana.pdf

Banerjee, H., Dhara, P. K., \& Mazumdar, D. (2009). Bamboo (Bambusa spp.) Based Agroforestry Systems under Rainfed Upland Ecosystem. Journal of Crop and Weed, 5, 288-292.

Banik, R. L. (1995). A Manual for Vegetative Propagation of Bamboos (66 p). International Network for Bamboo and Rattan (INBAR) UNDP/FAO Regional Forest Tree Improvement Project (FORTIP) and Bangladesh Forest Research Institute (BFRI). http://www.aha-kh.com/wp-content/uploads/2017/01/2-inbar-a-manual-for-vegetative -propagation-of-bamboos.pdf

Bareja, G. B. (2010). Bamboo Production and Propagation Methods. https://www.semanticscholar.org/paper/BAMBOO-PRODUCTION-AND-PROPAGA TION-METHODS-Bareja/f1efa938d7d019626b10a2b494471746022ec430

Bhol, N., \& Nayak, H. (2012). Effect of Planting Alignment and Cutting Size on Propagation of Bambusa vulgaris. Journal of Tree Sciences, 31, 69-75.

Bhol, N., \& Parida, S. (2015). Influence of Growth Regulators on Propagation of Culm and Branch Cuttings of Bambusa vulgaris. Journal of Tree Sciences, 34, 64-68.

Chaowana, P. (2013). Bamboo: An Alternative Raw Material for Wood and Wood Based composites. Journal of Material Science Research, 2, 90-102. https://doi.org/10.5539/jmsr.v2n2p90

Chhetri, S., \& Kumar, H. (2015). Effect of Planting Position on Rhizogenesis in Buddha Belly Bamboo (Bambu saventricosa) under Nursery Condition. Journal of International Academic Research for Multidisciplinary, 2, 283-289.

Chimi, C. D., Nfornkah, B. N., Forje, G. W., Awazi, N. P., Kaam, R., Nguefack, A. J., Tatang, M., Atoupka, A. M., Gansonkeng, Z. J. C., Tabue, M. R. B., Inimbock, S. L., \& Zapfack, L. (2021). Indigenous Knowledge of Bamboo Products and uses in the Western Highlands of Cameroon. Asian Journal of Research in Agriculture and Forestry, 7, 22-30. https://doi.org/10.9734/ajraf/2021/v7i230125

Choudhury, D., Sahu, J. K., \& Sharma, G. D. (2012). Value Addition to Bamboo Shoots: A Review. Journal of Food Science and Technology, 49, 407-414. https://doi.org/10.1007/s13197-011-0379-Z

Chung, K. F., \& Yu, W. K. (2002). Mechanical Properties of Structural Bamboo for Bamboo Scaffoldings. Engineering Structures, 24, 429-442. https://doi.org/10.1016/S0141-0296(01)00110-9

Degrande, A., Tadjo, P., Takoutsing, B., Asaah, E., Tsobeng, A., \& Tchoundjeu, Z. (2013). Getting Trees into Farmers' Fields: Success of Rural Nurseries in Distributing High Quality Planting Material in Cameroon. Small-Scale Forestry, 12, 403-420. 
https://doi.org/10.1007/s11842-012-9220-4

Dev, I., Ram, A., Ahlawat, S. P., Palsaniya, D. R., Singh, R., Dhyani, S. K., Kumar, N., Tewari, R. K., Singh, M., Babanna, S. K., Newaj, R., Dwivedi, R. P., Kumar, R. V., Yadav, R. S., Chand, L., Kumar, D., \& Prasad, J. (2020). Bamboo-Based Agroforestry System (Dendrocalamus strictus + Sesame-Chickpea) for Enhancing Productivity in Semi-Arid Tropics of Central India. Agroforestry Systems, 94, 1725-1739. https://doi.org/10.1007/s10457-020-00492-8

Elbasheer, Y. H. A., \& Raddad, E. A. Y. (2013). Vegetative Propagation of (Oxytenanthera abyssinica) by Culm Cuttings. Journal of Natural Resources and Environmental Studies, 1, 1-5.

Fokwa, D., Ngapgue, F., Mpessa, M., \& Tamo Tatietse, T. (2012). Physical Characterization of two Cameroon Bamboo Species: Arundinaria alpina and Oxytenantera abyssinica. International Journal of Engineering and Technology (IJET), 4, 82-92.

Fozao, D. S., Foudjet, A. E., Kouam, A., \& Fokwa, D. (2015). Modeling the Stress-Strain Behavior of Bamboo under Cyclic Uniaxial Loading. Revue Scientifique et Technique Forêt et Environnement du Bassin du Congo, 2, 9-27.

Gaintait, S., Pramanik, B. R., \& Banerjee, M. (2016). Optimization of Planting Materials for Large Scale Plantation of Bambusa balcooa Roxb.: Influence of Propagation Methods. Journal of the Saudi Society of Agricultural Sciences, 17, 79-87.

https://doi.org/10.1016/j.jssas.2015.11.008

Garima, D., Bhardwaj, R., Thakur, C. L., Kaushal, R., Sharma, P., Kumar, D., \& Kumari, Y. (2021). Bamboo-Based Agroforestry System Effects on Soil Fertility: Ginger Performance in the Bamboo Subcanopy in the Himalayas (India). Agronomy Journal, 113, 2832-2845. https://doi.org/10.1002/agj2.20684

Gebrehiwot, K., Woldetensae, T., Birhane, E., \& Tewolde-Berhan, S. (2016). Propagation Potential of the Lowland Bamboo through Seed and Culm Cuttings. Journal of Drylands, 6, 513-518.

Gebretsion, K., \& Abay, K. (2020). Evaluation of Different Propagation Methods of $O x y$ tenanthera abyssinica (A. Richard Munro) in Northwestern Tigray, Ethiopia. Asian Journal of Environment \& Ecology, 11, 1-7. https://doi.org/10.9734/ajee/2019/v11i430145

Gulabrao, A. Y., Kaushal, R., Tewari, K. S., Tomar, S. M. J., \& Chaturvedi, P. O. (2012). Seasonal Effect on Rooting Behaviour of Important Bamboo Species by Culm Cuttings. Journal of Forest Research, 23, 441-445 https://doi.org/10.1007/s11676-012-0282-0

Hossain, M. A., Jewel, M. E. U., Sen, M., \& Serajuddoula, M. (2006). Rooting ability of Bambusa vulgaris var. Striata Branch Cutting as Influenced by Cutting Types and Rooting Hormones. Journal of Bamboo and Rattan, 5, 117-126.

Ingram, V., \& Tieguhong, J. C. (2012). Bars to Jars: Bamboo Value Chains in Cameroon. Ambio, 42, 320-333. https://doi.org/10.1007/s13280-012-0347-5

Ingram, V., Tieguhong, C. J., Nkamgnia, M. E., Eyebe, P. J., \& Ngawe, M. (2010). The Bamboo Production to Consumption System in Cameroon. Working paper No. 50, Center for International Forestry Research (CIFOR).

Islam, M. S., Bhuiyan, M. K., Hossain, M. M., \& Hossain, M. A. (2011). Clonal Propagation of Bambusa vulgaris by Leafy Branch Cuttings. Journal of Forestry Research, 22, 387-392. https://doi.org/10.1007/s11676-011-0109-4

Joshi, R., Tewari, S. K., Kaushal, R., \& Tewari, L. (2012). Rooting Behaviour of Bambusa balcooa Roxb. in Relation to Season, Age and Growing Conditions. Indian Forester, 138, 79-83.

Kaushal, R., Gulabrao, Y. A., Tewari, S. K., Chaturvedi, S., \& Chaturvedi, O. P. (2011). 
Rooting Behaviour and Survival of Bamboo Species Propagated through Branch Cuttings. Indian Journal of Soil Conservation, 39, 171-175.

Kaware, A., Awari, U. R., \& Wakchaure, M. R. (2013). Review of Bamboo as Reinforcement Material in Concrete Structures. International Journal of Innovative Research in Science, Engineering and Technology, 2, 2461-2464.

Kittur, B. H., Sudhakara, K., Mohan Kumar, B., Kunhamu, T. K., \& Sureshkumar, P. (2016). Bamboo Based Agroforestry Systems in Kerala, India: Performance of Turmeric (Curcuma longa L.) in the Subcanopy of Differentially Spaced Seven Year-Old Bamboo Stand. Agroforestry Systems, 90, 237-250. https://doi.org/10.1007/s10457-015-9849-Z

Liese, W. (1999). Bamboo: Past-Present-Future (Vol. 20). American Bamboo Society.

Lin, X., Huang, L., \& Fang, W. (2012). Bamboo Regeneration via Embryogenesis and Organogenesis. In S. Ken-Ichi (Ed.), Embryogenesis (pp. 359-372). IntechOpen. https://doi.org/10.5772/37138

Mankou, V. (2018, May 5). Bamboo Industrialization Opportunities in Cameroon: Myth or Reality.

https://forest4dev.org/bamboo-industrialization-opportunities-in-cameroon-myth-or-r eality/

Mehra, S. R., \& Mehra, L. K. (2007). Bamboo Cultivation-Potential and Prospects. Technical Digest, 10, 26-31.

https://ccsindia.org/bamboo/2e-bamboo-ciltivation-potential-and-prospects.pdf

Mishra, V. (2015). Bamboo and Its Connectivity to the Different Fields of Economics: A Potential Resource of Modern India. International Journal of Innovative Research \& Development, 4, 140-145.

Mudoi, D. K., Saikla, P. S., Goswami, A., Gogoi, A., Bora, D., \& Borthakur, M. (2013). Micropropagation of Important Bamboos: A Review. African Journal of Biotechnology, 12, 2770-2785.

Mulatu, Y., \& Fetene, M. (2014). Propagation Techniques for Highland Bamboo (Arundinaria alpina) in the Choke Mountain, Northwestern Ethiopia. Ethiopian Journal of Agricultural Sciences, 24, 22-35.

https://www.eefri.org/wp-content/uploads/2016/01/Bamboo-propagation...JA_.pdf

Nath, S., Das, R., Chandra, R., \& Sinha, A. (2009). Bamboo Based Agroforestry for Marginal Lands with Special Reference to Productivity, Market Trend and Economy (26 p). https://citeseerx.ist.psu.edu/viewdoc/download?doi=10.1.1.564.1866\&rep=rep1\&type= pdf

Nfornkah, B. N., Tchamba, M., Chimi, C. D., Forje, G. W., \& Mairong, F. (2018). Indigenous Knowledge on Irvingia gabonensis (Bush Mango) Sustainability in the Takamanda National Park (TNP) Communities, South West Cameroon. Forests, Trees and Livelihoods, 27, 257-263. https://doi.org/10.1080/14728028.2018.1512423

Nfornkah, B. N., Kaam, R., Zapfack, L., Tchamba, M., \& Chimi, C. D. (2020a). Bamboo Diversity and Carbon Stocks of Dominant Species in Different Agro-Ecological Zones in Cameroon. African Journal of Environmental Science and Technology, 14, 290-300. https://doi.org/10.5897/AJEST2020.2871

Nfornkah, B. N., Chimi, C. D., Forje, G. W., \& Kaam, R. (2020b). Bamboo Policy Integration Analysis Cameroon (31 p). International Network for Bamboo and Rattan (INBAR).

Nfornkah, B. N., Kaam, R., Tchamba, M., Zapfack, L., Chimi, C. D., \& Tanougong, A. T. (2020c). Assessing the Spatial Distribution of Bamboo Species Using Remote sensing in Cameroon. Journal of Ecology and the Natural Environment, 12, 172-183.

Nfornkah, B. N., Kaam, R., Tchamba, M., Zapfack, L., Chimi, D. C., Forje, G. W., Tanougong, A. D., Tsewoue, M. R., Atchombou, J. B., Tientcheu, L., Tchoutezou, Z. G. 
H., Kede, Y., \& Djeukam, S. V. (2021a). Culm Allometry and Carbon Storage Capacity of Bambusa vulgaris Schrad. ex J. C. Wend L. in the Tropical Evergreen Rain Forest of Cameroon. Journal of Sustainable Forestry, 40, 622-638. https://doi.org/10.1080/10549811.2020.1795688

Nfornkah, B. N., Kaam, R., Zapfack, L., Tchamba, M., Chimi, C. D., Forje, G. W., Tanougong, A. N. D., Tsewoue, M. R., Nguefack, J. A., Gansonkeng, Z. J. C., \& Okala, S. (2021b). Spatial Distribution and Carbon Storage of a Native Bamboo Species in the High Guinea Savannah of Cameroon: Oxytenanthera abyssinica (A. Rich.) Munro. International Journal of Environmental Studies, 78, 504-516.

https://doi.org/10.1080/00207233.2020.1824972

Nfornkah, B. N., Enongene, K., Kaam, R., Tanougong, A. D., Chimi, C. D., Forje, G. W., \& Awazi, N. P. (2021c). Growth Potential and Sustainability of Economically Important Rattan Species in Agro-Ecological Zones of Cameroon (52 p). International Network for Bamboo and Rattan (INBAR).

Nirala, D. P., Kumar, J., Ahmad, S., \& Kumari, P. (2018). Bamboo Based Agroforestry System for Livelihood and Ecological Security in North Chhotanagpur Division of Jharkhand. Journal of Pharmacognosy and Phytochemistry, 7, 1996-1999.

Nongdam, P., \& Tikendra, L. (2014). The Nutritional Facts of Bamboo Shoots and Their Usage as Important Traditional Foods of Northeast India. International Scholarly Research Notices, 2014, Article ID: 679073. https://doi.org/10.1155/2014/679073

Ntirugulirwa, B., Asiimwe, T., Gapusi, J., Mutaganda, A., Nkuba, G., Ruzindana, N. A., Ntabana, D., Barnabé, B., Kahia, J., \& Gahakwa, D. (2012). Influence of Bud Position on Mother Stem and Soaking Duration on Sprouting of Bamboo. Rwanda Journal, 28, 3-10. https://doi.org/10.4314/rj.v28i0.1

Partey, S., Sarfo, D., Frith, O., Kwaku, M., \& Thevathasan, N. (2017). Potentials of Bamboo-Based Agroforestry for Sustainable Development in Sub-Saharan Africa: A Review. Agricultural Research, 6, 22-32. https://doi.org/10.1007/s40003-017-0244-Z

Pattanaik, S., Das, P., Borah, E., \& Kaur, K. (2004). Vegetative Multiplication of Bambusa balcooa Roxb. Using Branch Cuttings. Journal of Bamboo and Rattan, 4, 365-374.

Poudel, R. C. (2020, August 23). Bamboo Biomass: A Potential Bio-Resource for Sustainable Development. https://www.greenesa.com/news/bamboo-biomass-for-sustainable-development

Ray, S. S., \& Ali, M. N. (2016). Evaluation of Inexpensive Bedding Materials for Culm Cutting of Bambusa Balcooa Roxb. and Its Field Performance. Journal of Biotechnology and Biomaterials, 6, Article No. 227. https://doi.org/10.4172/2155-952X.1000227

Ray, S. S., \& Ali, M. N. (2017). Factors Affecting Macropropagation of Bamboo with Special Reference to Culm Cuttings: A Review Update. New Zealand Journal of Forestry Science, 47, Article No. 17. https://doi.org/10.1186/s40490-017-0097-z

Razvi, S., Nautiyal, S., Bakshi, M., Bhat, J. A., \& Pala, N. A. (2011). Influence of Season and Phytohormoneson Rooting Behaviour of Green Bamboo by Cuttings. International Journal of Conservation Science, 2, 199-206.

Ruíz-Pérez, M., Belcher, B., Fu, M., \& Yang, X. (2004). Looking through the Bamboo Curtain: An Analysis of the changing Role of Forest and Farm Income in Rural Livelihoods in China. International Forestry Review, 6, 306-316.

https://doi.org/10.1505/ifor.6.3.306.59968

Saad, M., Kumar, H., \& Umrao, R. (2016). Effect of the Different Growth Regulators on Vegetative Propagation of Buddha Belly Bamboo. Advances in Life Sciences, 5, 1310-1314.

Senyanzobe, J. M. V., Jennifer, R., Grace, M., Faustin, N., Gaudence, M., \& Dieu, R. R. J. 
D. (2013). Growth of Bambusa vulgaris and Araundinaria alpina under Different Nursery Site Conditions at the Higher Institute of Agriculture and Animal Husbandry, Northern Rwanda. Journal of Biodiversity and Environmental Sciences, 3, 9-14.

Shukla, R., Sumit, G., Sajal, S. P. K., \& Dwivedi, A. M. (2015). Medicinal Importance of Bamboo. International Journal of Biopharm \& Phytochemical Research, 1, 9-15.

Sikame-Tagne, N., Abessolo, D., Harzallah, O., Ndapeu, D., Huisken, W., Nkemaja, D., Biwole, A., Mbou, T. E., Njeugna, E., Fogue, M., Drean, J.-Y., \& Bistac, S. (2021). Physico-Chemical and Mechanical Characterization of Bambusa Vulgaris Fibers from Cameroon. Journal of Composite Materials, 55, 2489-2502. https://doi.org/10.1177/0021998321992537

Singh, R. S., Singh, R., Kalia, S., Dalal, S., Dhawan, K. A., \& Kalia, K. R. (2013). Limitations, Progress and Prospects of Application of Biotechnological Tools in Improvement of Bamboo: A Plant with Extraordinary Qualities. Physiology and Molecular Biology of Plants, 19, 21-41. https://doi.org/10.1007/s12298-012-0147-1

Singh, S., Nain, N. P. S., Nain, S. L., \& Tripathi, S. P. (2006). Patterns of Adventitious Root Induction during Different Seasons in Some Bamboo Species. Journal of Bamboo and Rattan, 5, 101-107.

Solomon, T., Moon, H. J., Abebe, S., Minale, A. S., \& Teketay, D. (2020). Promoting Bamboo-Based Agroforestry for Enhancing Ecosystem Services from Degraded Lands. In J. C. Dagar, S. R. Gupta, \& D. Teketay (Eds.), Agroforestry for Degraded Landscapes (pp. 423-444). Springer. https://doi.org/10.1007/978-981-15-6807-7_16

Takoutsing, B., Tchoundjeu, Z., Degrande, A., Asaah, E., \& Tsobeng, A. (2014). Scaling-up Sustainable Land Management Practices through the Concept of the Rural Resource Centre: Reconciling Farmers' Interests with Research Agendas. The Journal of Agricultural Education and Extension, 20, 463-483.

https://doi.org/10.1080/1389224X.2014.913984

Takoutsing, B., Tchoundjeu, Z., Degrande, A., Asaah, E., Gyau, A., Nkeumoe, F., \& Tsobeng, A. (2013). Assessing the Quality of Seedlings in Small-Scale Nurseries in the Highlands of Cameroon: The Use of Growth Characteristics and Quality Thresholds as Indicators. Small-Scale Forestry, 13, 65-77. https://doi.org/10.1007/s11842-013-9241-7

Tewari, S., Banik, R. L., Kaushal, R., Bhardwaj, D. R., Chaturvedi, O. P., \& Gupta, A. (2015). Bamboo Based Agroforestry Systems (24 p).

http://frienvis.nic.in/WriteReadData/UserFiles/file/Content-Page/Books/Bamboo/Bam boo-Based-Agroforestry.pdf

Tripathi, Y. C. (2009). Propagating Bamboo (2 p). https://www.researchgate.net/publication/273205350_Propagating_Bamboo?channel= doi\&linkId=54fbefbd0cf20700c5e833ac\&showFulltext=true

Yadav, Y., Chhetri, B., Raymajhi, S., Tiwari, K., \& Sitaula, B. (2020). Evaluating Contribution of Trees Outside Forests for Income of Rural Livelihoods of Terai Region of Nepal. Open Journal of Forestry, 10, 388-400. https://doi.org/10.4236/ojf.2020.104024

Yi, L. (2018, April 10). Innovative Technology Turns Bamboo Forests into Valuable Assets. China Today. http://www.chinatoday.com.cn/ctenglish/2018/et/201804/t20180410_800126222.html

Yuming, Y., Kanglin, W., Shengji, P., \& Jiming, H. (2004). Bamboo Diversity and Traditional Uses in Yunnan, China. Mountain Research and Development, 24, 157-165. https://doi.org/10.1659/0276-4741(2004)024[0157:BDATUI]2.0.CO;2 